\title{
ॠUSES
}

science for a changing world

Prepared in cooperation with King County Department of Natural Resources and Parks

Water Temperature Profiles for Reaches of the Raging River during Summer Baseflow, King County, Western Washington, July 2015

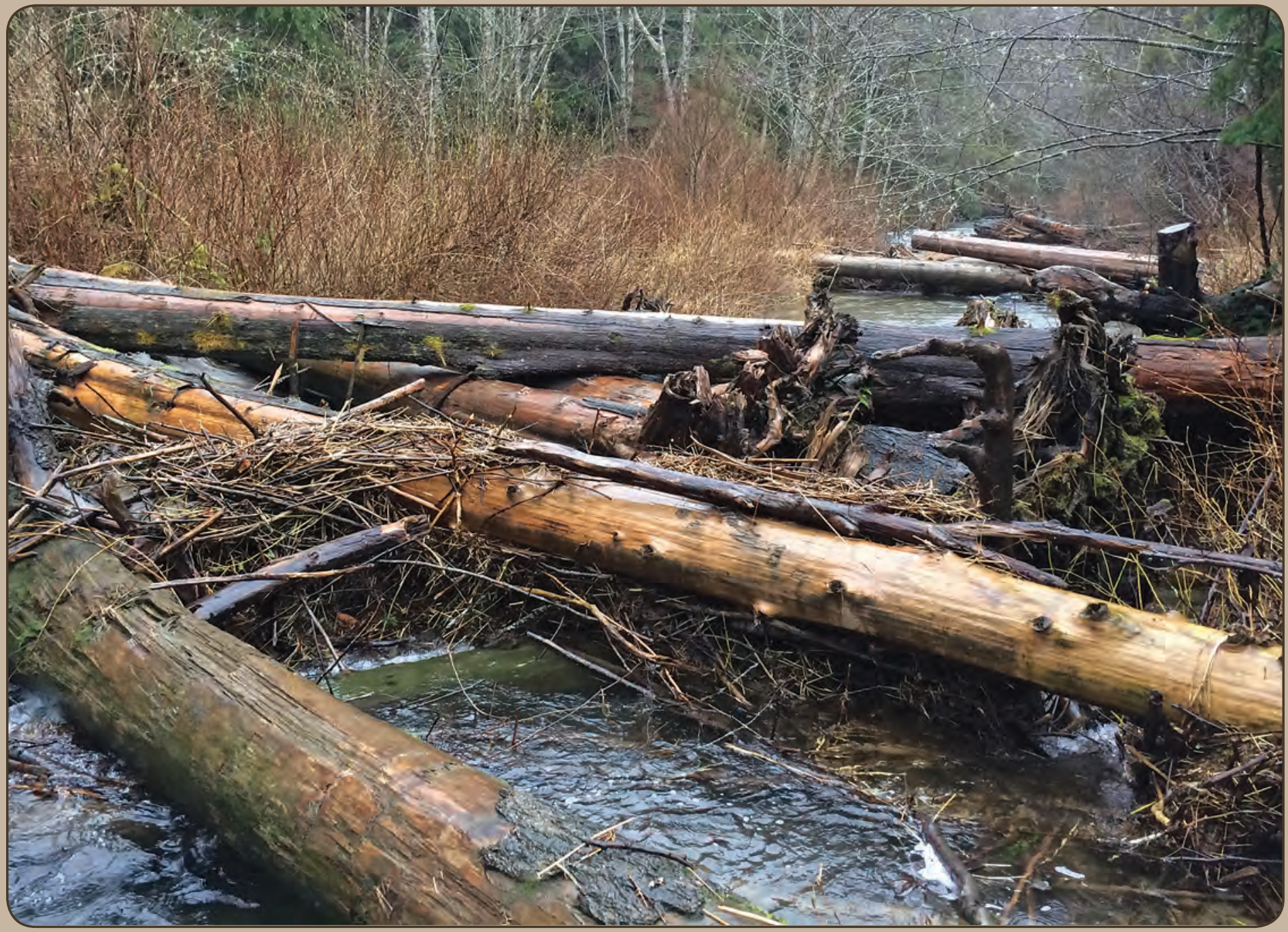

Data Series 983 
Cover: Photograph showing large wood placements in Raging River, King County, Washington. Photograph by Andrew Gendaszek, U.S. Geological Survey, March 19, 2014. 


\section{Water Temperature Profiles for \\ Reaches of the Raging River during Summer Baseflow, King County, Western Washington, July 2015}

By Andrew S. Gendaszek and Chad C. Opatz

Prepared in cooperation with King County Department of Natural Resource and Parks

Data Series 983 


\title{
U.S. Department of the Interior SALLY JEWELL, Secretary
}

\section{U.S. Geological Survey Suzette M. Kimball, Director}

\author{
U.S. Geological Survey, Reston, Virginia: 2016
}

For more information on the USGS - the Federal source for science about the Earth, its natural and living resources, natural hazards, and the environment—visit http://www.usgs.gov or call 1-888-ASK-USGS.

For an overview of USGS information products, including maps, imagery, and publications, visit http://www.usgs.gov/pubprod/.

Any use of trade, firm, or product names is for descriptive purposes only and does not imply endorsement by the U.S. Government.

Although this information product, for the most part, is in the public domain, it also may contain copyrighted materials as noted in the text. Permission to reproduce copyrighted items must be secured from the copyright owner.

Suggested citation:

Gendaszek, A.S., and Opatz, C.C., 2016, Water temperature profiles for reaches of the Raging River during summer baseflow, King County, western Washington, July 2015: U.S. Geological Survey Data Series 983, 8 p., http://dx.doi.org/10.3133/ds983.

ISSN 2327-638X (online) 


\section{Contents}

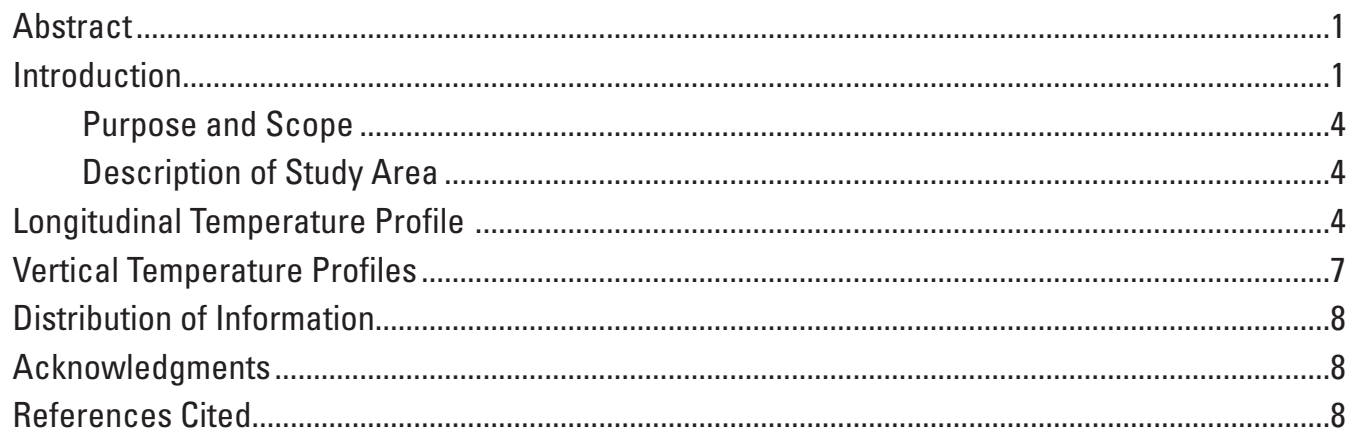

\section{Figures}

1. Map showing location of Raging River, King County, western Washington...... 2

2. Map showing Raging River study reach and deployment of fiber-optic distributed sensor from reach meter 0 to reach meter 1,026, King County, western Washington......3

3. Thermograph showing near-streambed temperature of the 1,026-meter study reach measured using fiber-optic distributed temperature sensor, Raging River, King County, western Washington, July 7-13, 2015.

4. Map showing near-streambed temperature measured on July 8, 2015, at 1645, and standard deviation of near-streambed temperatures measured between July 7 and 13, 2015, using fiber-optic distributed temperature sensor in 1,026-meter study reach of Raging River, King County, western Washington

5. Vertical temperature profiles measured at reach meters 741, 780, 821, and 902 from upstream end of Raging River study reach, King County, western Washington, July 7-13, 2015 .

\section{Tables}

1. Near-streambed water temperature data for longitudinal thermal profile of Raging River, King County, western Washington, July 7-13, 2015.

2. Location data for near-streambed water temperature measurement locations for longitudinal profile of Raging River, King County, western Washington

3. Water temperature data for vertical profiles at four locations along longitudinal temperature profile of Raging River, western Washington, July 7-13, 2015. 


\section{Conversion Factors}

International System of Units to Inch/Pound

\begin{tabular}{|c|c|c|}
\hline Multiply & By & To obtain \\
\hline \multicolumn{3}{|c|}{ Length } \\
\hline centimeter $(\mathrm{cm})$ & 0.3937 & inch (in) \\
\hline meter $(\mathrm{m})$ & 3.281 & foot $(\mathrm{ft})$ \\
\hline kilometer (km) & 0.621 & mile (mi) \\
\hline \multicolumn{3}{|c|}{ Area } \\
\hline square meter $\left(\mathrm{m}^{2}\right)$ & 0.0002471 & acre \\
\hline square kilometer $\left(\mathrm{km}^{2}\right)$ & 247.1 & acre \\
\hline square kilometer $\left(\mathrm{km}^{2}\right)$ & 0.3861 & square mile $\left(\mathrm{mi}^{2}\right)$ \\
\hline \multicolumn{3}{|c|}{ Volume } \\
\hline cubic meter $\left(\mathrm{m}^{3}\right)$ & 35.31 & cubic foot $\left(\mathrm{ft}^{3}\right)$ \\
\hline \multicolumn{3}{|c|}{ Flow rate } \\
\hline cubic meter per second $\left(\mathrm{m}^{3} / \mathrm{s}\right)$ & 70.07 & acre-foot per day (acre-ft/d) \\
\hline cubic meter per second $\left(\mathrm{m}^{3} / \mathrm{s}\right)$ & 35.31 & cubic foot per second $\left(\mathrm{ft}^{3} / \mathrm{d}\right)$ \\
\hline
\end{tabular}

Temperature in degrees Celsius $\left({ }^{\circ} \mathrm{C}\right)$ may be converted to degrees Fahrenheit $\left({ }^{\circ} \mathrm{F}\right)$ as

$$
{ }^{\circ} \mathrm{F}=\left(1.8 \times{ }^{\circ} \mathrm{C}\right)+32
$$

\section{Datum}

Horizontal coordinate information is referenced to the North American Datum of 1983 (NAD 83).

\section{Abbreviations}

FO-DTS fiber-optic distributed temperature sensor

NIST National Institute of Standards and Technology

USGS U.S. Geological Survey 


\title{
Water Temperature Profiles for Reaches of the Raging River during Summer Baseflow, King County, Western Washington, July 2015
}

\author{
By Andrew S. Gendaszek and Chad C. Opatz
}

\section{Abstract}

Re-introducing wood into rivers where it was historically removed is one approach to improving habitat conditions in rivers of the Pacific Northwest. The Raging River drainage basin, which flows into the Snoqualmie River at Fall City, western Washington, was largely logged during the 20th century and wood was removed from its channel. To improve habitat conditions for several species of anadromous salmonids that spawn and rear in the Raging River, King County Department of Transportation placed untethered log jams in a 250 -meter reach where wood was historically removed. The U.S. Geological Survey measured longitudinal profiles of near-streambed temperature during summer baseflow along 1,026 meters of channel upstream, downstream, and within the area of wood placements. These measurements were part of an effort by King County to monitor the geomorphic and biological responses to these wood placements. Near-streambed temperatures averaged over about 1-meter intervals were measured with a fiber-optic distributed temperature sensor every 30 minutes for 7 days between July 7 and 13, 2015. Vertical temperature profiles were measured coincident with the longitudinal temperature profile at four locations at 0 centimeters $(\mathrm{cm})$ (at the streambed), and 35 and $70 \mathrm{~cm}$ beneath the streambed to document thermal dynamics of the hyporheic zone and surface water in the study reach.

\section{Introduction}

The Raging River drains an $83-\mathrm{km}^{2}\left(32-\mathrm{mi}^{2}\right)$ area of the foothills of the Cascade Range, western Washington (fig. 1) and provides spawning and rearing habitat for anadromous salmonids. During the 20th century, the Raging River drainage basin was logged and in-channel wood was removed, which can result in reduced geomorphic complexity (Gurnell and others, 2002; Montgomery and Piegay, 2003). Large, in-channel wood forms habitat in fluvial ecosystems of the Pacific Northwest that supports salmonids including Chinook salmon (Oncorhynchus tshawytscha) and steelhead (Oncorhynchus mykiss) that are listed as threatened under the Endangered Species Act in Puget Sound.

Salmonid habitat lost to emergency placement of riprap in the lower Raging River during a flood in January 2009 was mitigated by placements of wood in summer 2009 between 350 and $600 \mathrm{~m}$ downstream of the upstream end of the study reach (fig. 2). Longitudinal distances in the study reach are referenced throughout the report in the downstream direction such that reach meter 0 is located at the upstream end of the reach. The untethered wood was free to move downstream during subsequent high flows and to reorganize itself within the channel and floodplain, and by summer 2015, only one of the jams placed across the channel in 2009 remained in place. Downstream transport of the introduced wood resulted in the formation of one new channel-spanning log jam in place in summer 2015 near reach meter 750 (fig. 2). Additionally, introduced wood was entrained in several existing log jams throughout the study reach. One of the jams that was supplemented with introduced wood was channel-spanning at reach meter 1,000 (fig. 2).

In summer 2015, King County led an effort to assess the redistribution of placed wood in the study reach and to assess geomorphic and biological conditions immediately upstream of, within, and downstream of the 2009 wood placement. Placed wood can cause structural changes to in-channel habitat for salmonids (for example, Pess and others, 2012). Additionally, placed wood also can create deep pools that increase hydraulic gradients and hyporheic exchange, resulting in thermal diversity (Sawyer and others, 2012). Depending on resulting temperature conditions, thermal diversity may help provide thermal refugia for salmonids (Torgersen and others, 2012). To augment the geomorphic and biological assessments by King County of habitat conditions in the study reach related to wood placements, the U.S. Geological Survey (USGS) continuously measured a longitudinal profile of stream temperature for 7 days during summer baseflow and measured vertical temperature profiles within the streambed at four locations along the longitudinal profile. 


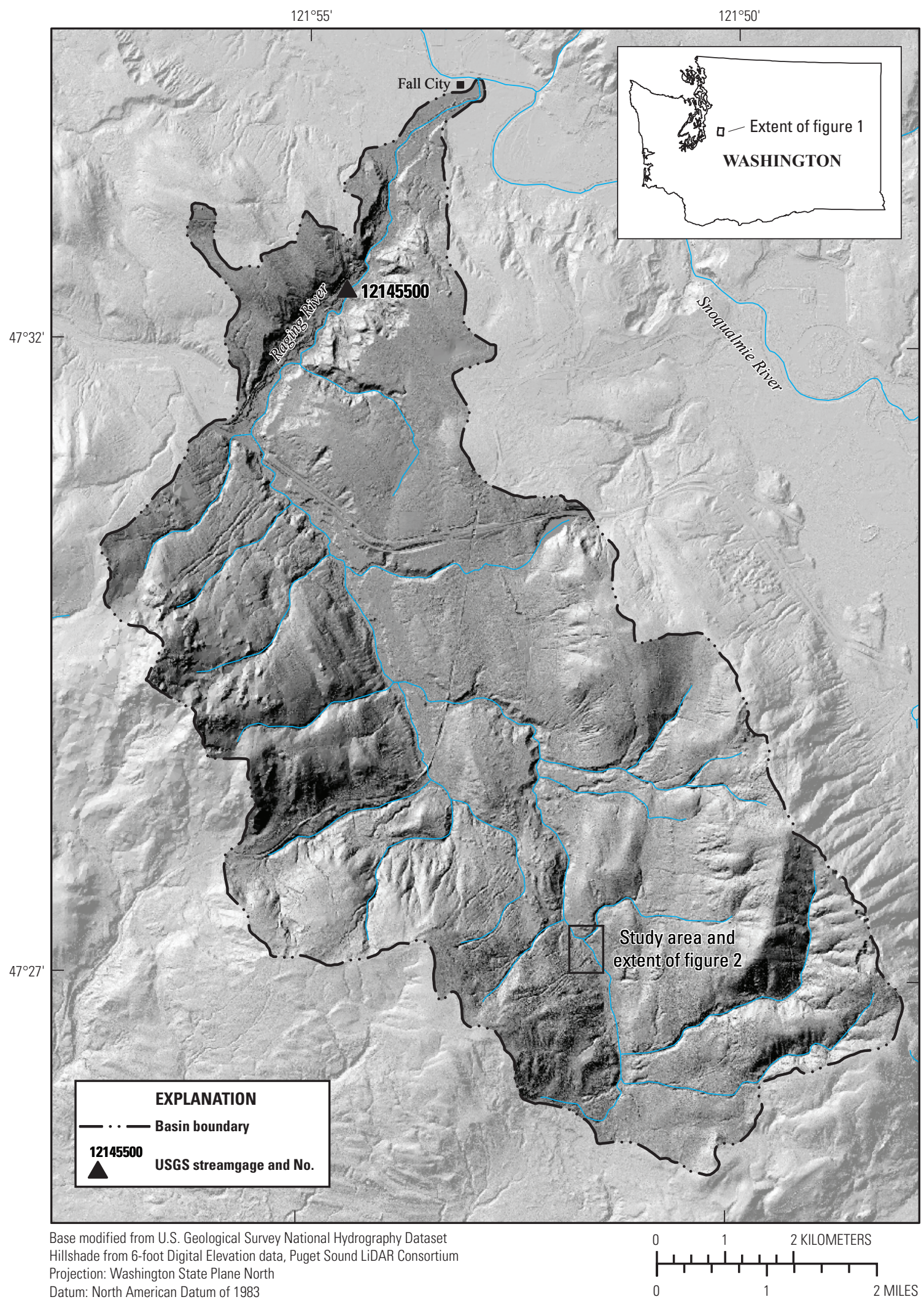

Figure 1. Location of Raging River, King County, western Washington. 


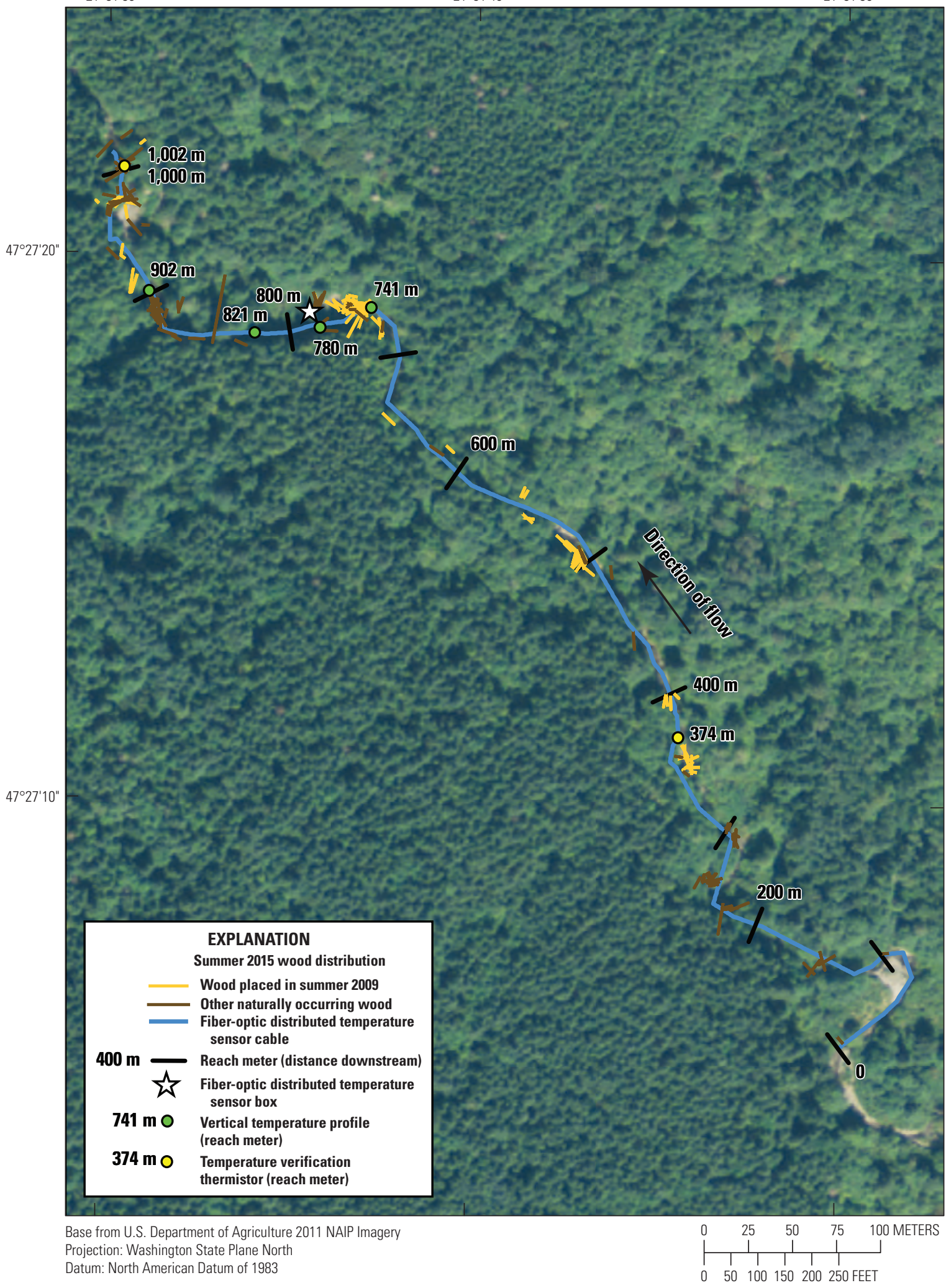

Figure 2. Raging River study reach and deployment of fiber-optic distributed sensor from reach meter 0 (upstream end of reach) to reach meter 1,026 (downstream end of reach), King County, western Washington. 
The longitudinal temperature profile was collected using a fiber-optic distributed temperature sensor (FO-DTS), which has been applied to hydrological investigations concerning groundwater/surface-water investigations (for example, Selker and others, 2006; Lowry and others, 2007; Briggs and others, 2012).

\section{Purpose and Scope}

The purpose of this report is to present water temperature data collected upstream of, within, and downstream of the wood placements in the Raging River during summer baseflow in July 2015. These data include (1) a 1,026-m-long longitudinal profile of near-streambed temperatures measured at about $1-\mathrm{m}$ intervals every 30 minutes with a FO-DTS and (2) four vertical profiles of stream temperature measured at $0 \mathrm{~cm}$ (at the streambed), and 35 and $70 \mathrm{~cm}$ beneath the streambed. These vertical profiles were located at the heads of pools formed by large wood jams where head differences were hypothesized to lead to discharge of hyporheic water into the stream. These data were collected to complement the contemporaneous monitoring by King County of the geomorphic and biological responses to wood placements in the Raging River.

\section{Description of Study Area}

The Raging River drains mostly undeveloped forest land in the foothills of the Cascade Range (fig. 1), which was largely logged in the 20th century. A 1,026-m reach of the upper Raging River was selected to include the channel upstream of, within, and downstream of log jams placed in summer 2009 (fig. 2). By 2015, when the thermal profiles presented in this report were measured, the placed wood had been moved by high flows downstream of the locations of their original placement. The climate of the study area is characterized by cool, wet winters and warm, dry summers with most precipitation falling as rain during the winter months. Mean monthly streamflow measured at the Raging River near Fall City (USGS streamgage 12145500) from water years 1946 to 2015 ranges from a maximum of $7.7 \mathrm{~m}^{3} / \mathrm{s}$ $\left(273 \mathrm{ft}^{3} / \mathrm{s}\right)$ in January to a minimum of $0.50 \mathrm{~m}^{3} / \mathrm{s}\left(18 \mathrm{ft}^{3} / \mathrm{s}\right)$ in August.

\section{Longitudinal Temperature Profile}

Near-streambed water temperature was measured from July 7 to 13,2015 , every 30 minutes over about 1-m intervals using a FO-DTS installed on the streambed of a 1,026-m reach of the Raging River. Temperature measurement sections were $1.01 \mathrm{~m}$, resulting in a 1,026-m reach covered by 1,012 temperature measurement locations. Because of drought conditions during water year 2015, streamflow of the Raging River reached baseflow conditions by early July. Mean daily streamflow measured at the Raging River near Fall City (USGS streamgage 12145500) ranged from 0.28 to $0.31 \mathrm{~m}^{3} / \mathrm{s}$ $\left(9.9-11 \mathrm{ft}^{3} / \mathrm{s}\right)$ between July 7 and 13,2015 . The FO-DTS measures temperature along the length of a fiber-optic cable by emitting a pulse of laser light at a known wavelength and measuring Raman-backscattered light that returns at a higher (Stokes) and lower (anti-Stokes) wavelength (Selker and others, 2006). Unlike the Stokes wavelength intensity, the intensity of light that returns at the anti-Stokes wavelength is strongly affected by temperature; temperature at a given location of the fiber-optic cable is determined by measuring the time-of-travel of the laser pulse propagation and the ratio of the Stokes and anti-Stokes intensities. Temperature was measured using two separate fiber-optic cables by configuring the FO-DTS to measure two single-ended measurements where light was emitted in one direction through each cable. A 786-m cable measured temperature from reach meter 0 to 786 in the upstream part of the study reach, and a second $240-\mathrm{m}$ cable measured temperature from reach meter 786 to 1,026 in the downstream part of the study reach.

Each fiber-optic cable was initially calibrated by placing both ends of the fiber-optic cable in a constant-temperature ice bath $\left(0.0^{\circ} \mathrm{C}\right)$ verified with a National Institute of Standards and Technology (NIST)-certified thermistor with an accuracy of $\pm 0.1^{\circ} \mathrm{C}$. Data-logging thermistors (Hobo ${ }^{\circledR}$ Water Temp Pro v2) were deployed at calibration points along the fiber-optic cable and independently recorded near-streambed water temperature. These measurements were used to dynamically calibrate the FO-DTS at each time step by serving as input to solve a set of linear equations (Hausner and others, 2011). The root mean square errors of two verification points recorded by data-logging thermistors $\left(\right.$ Hobo $^{\circledR}$ Water Temp Pro v2) deployed in addition to the calibration thermistors were 0.38 at reach meter 374 downstream (located $412 \mathrm{~m}$ from the FO-DTS unit) and 0.17 at reach meter 1,002 (located $216 \mathrm{~m}$ from the fiber-optic unit). Error between temperature measured by the FO-DTS and data-logging thermistor increases with distance from the FO-DTS unit, which emits the pulse of light through the fiber-optic cable, because the amount of backscattered light decreases with distance. 
A thermograph shows that diurnal fluctuations in near-streambed water temperatures ranged from about 12 to $18{ }^{\circ} \mathrm{C}$ and were warmest in late afternoon and coolest at dawn (fig. 3). The first three days of the FO-DTS deployment were warm and sunny, whereas clouds moderated air temperatures during the remainder of the FO-DTS deployment. Large changes in diurnal temperatures occurred at four locations in the fiber-optic deployment near reach meters $155,365,975$, and 1,010, where the fiber-optic cable was not submerged in the wetted channel because of channel-spanning obstacles such as log jams (fig. 3).
Temperature measured at each 30-minute time step of the FO-DTS deployment also may be plotted in map view along the study reach. For example, temperature measured on July 8,2015 , at 1645 near the daily maximum stream temperature in late afternoon is shown in figure 4 . The coolest stream temperatures measured at this time generally were measured between reach meters 200 and 300, which also were among the part of the study reach with the least variable near-streambed temperatures with the lowest standard deviation during the FO-DTS deployment (fig. 4). By contrast, the warmest stream temperatures measured on July 8, 2015, at 1645 occurred near reach meter 800 , which also were among the most variable near-streambed temperatures measured during the FO-DTS deployment.

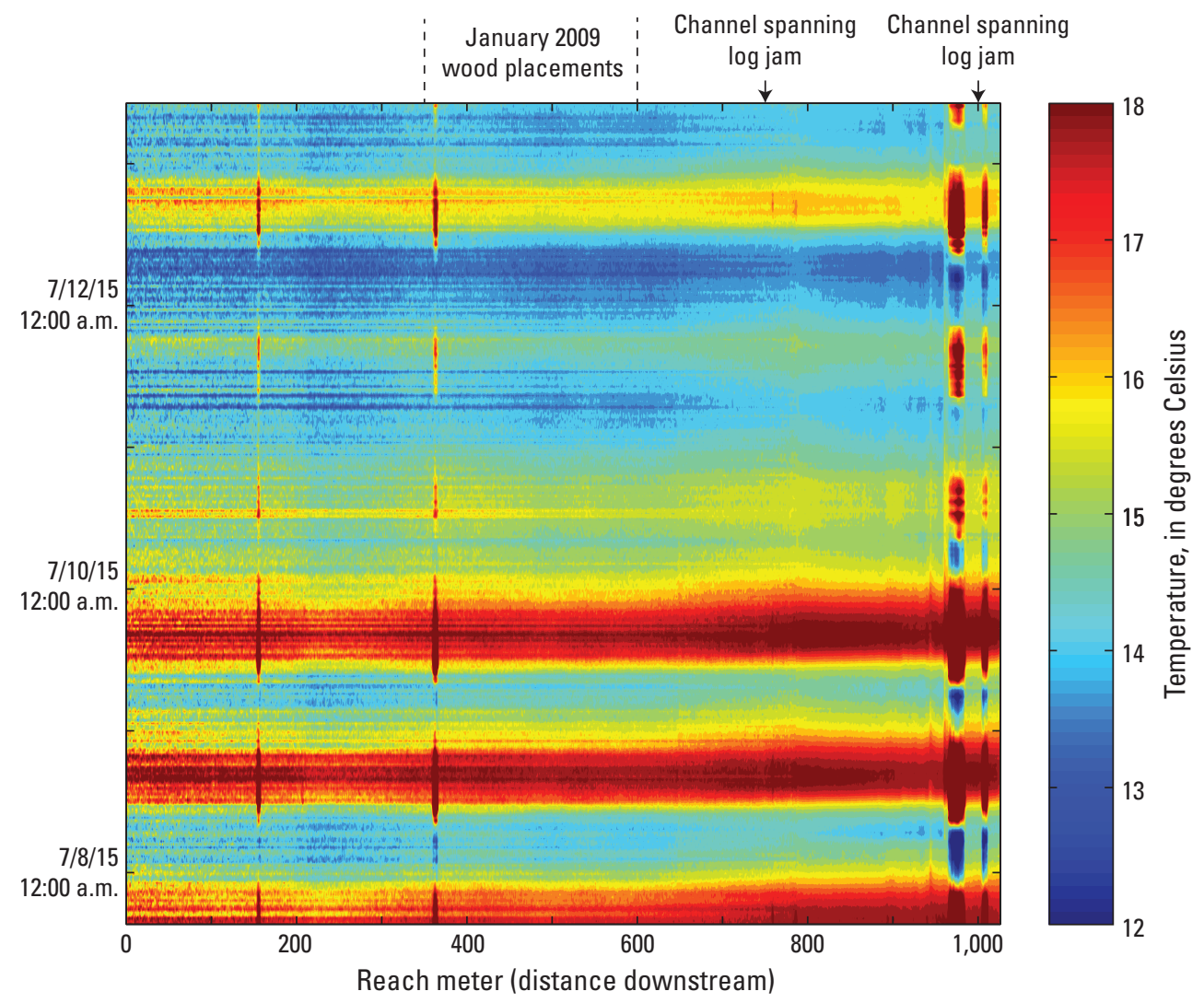

Figure 3. Thermograph showing near-streambed temperature of the 1,026-meter study reach measured using fiber-optic distributed temperature sensor, Raging River, King County, western Washington, July 7-13, 2015. Reach meters are the distance downstream of the upstream end of the study reach. 


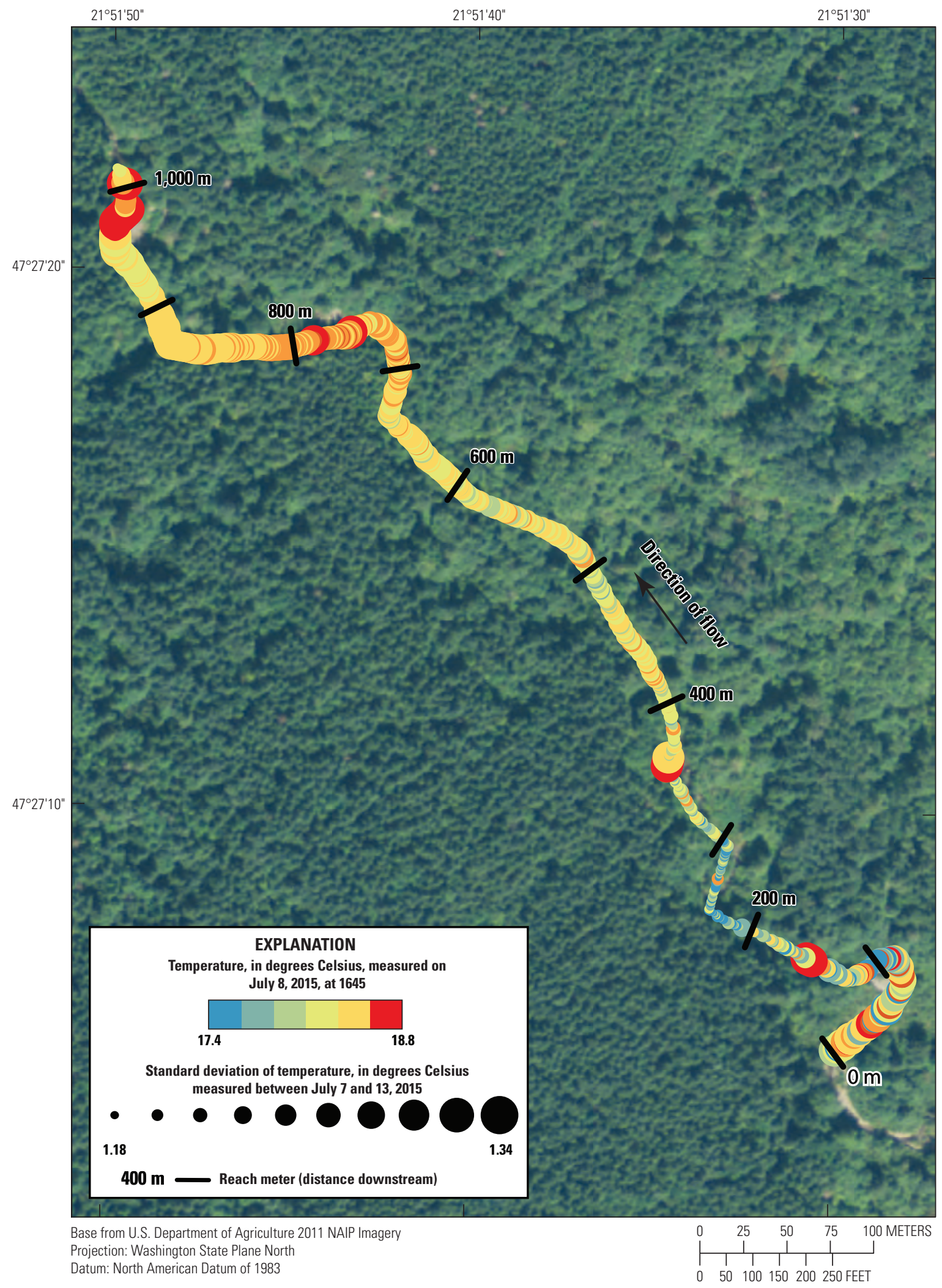

Figure 4. Near-streambed temperature measured on July 8 , 2015, at 1645 , and standard deviation of near-streambed temperatures measured between July 7 and 13, 2015, using fiber-optic distributed temperature sensor in 1,026-meter study reach of Raging River, King County, western Washington. 


\section{Vertical Temperature Profiles}

Four vertical temperature profiles were measured coincident with the longitudinal temperature profile from July 7 to 13, 2015, at reach meters 741, 780, 821, and 902. Vertical temperature profiles were measured by deploying three thermistors $\left(\mathrm{Hobo}^{\circledR}\right.$ Water Temp Pro v2 or Solinst Levelogger ${ }^{\circledR}$ Edge Model 3001) within shallow piezometers at each of the four sites programmed to record temperature at 15 -minute intervals. The calibration of each thermistor was verified with a NIST-certified thermistor with an accuracy of $\pm 0.1^{\circ} \mathrm{C}$ prior to deployment in the field. At each site, thermistors were deployed in a piezometer such that the deepest thermistor was deployed $70 \mathrm{~cm}$ beneath the streambed, the mid-depth thermistor was deployed $35 \mathrm{~cm}$ beneath the streambed, and the shallowest thermistor was deployed at $0 \mathrm{~cm}$ (at the streambed). Diurnal fluctuations in temperature measured at the streambed $(0 \mathrm{~cm})$ at reach meters 821 and 902 along the FO-DTS deployment were similar in phase and amplitude to the diurnal fluctuations recorded at $35 \mathrm{~cm}$ beneath the streambed (fig. 5). Although diurnal temperature fluctuations recorded at $70 \mathrm{~cm}$ beneath the streambed also were in phase with those recorded at the surface at reach meter 821, they were lower in amplitude and out of phase with surface diurnal temperature fluctuations recorded at reach meter 902 .

Conversely, thermographs measured at 35 and $70 \mathrm{~cm}$ beneath the streambed at reach meters 741 and 780 did not vary diurnally like the thermograph measured at the streambed $(0 \mathrm{~cm})$ at these locations.

Figure 5. Vertical temperature profiles measured at reach meters $741(A), 780(B), 821(C)$, and 902 $(D)$ from upstream end of Raging River study reach, King County, western Washington, July 7-13, 2015.
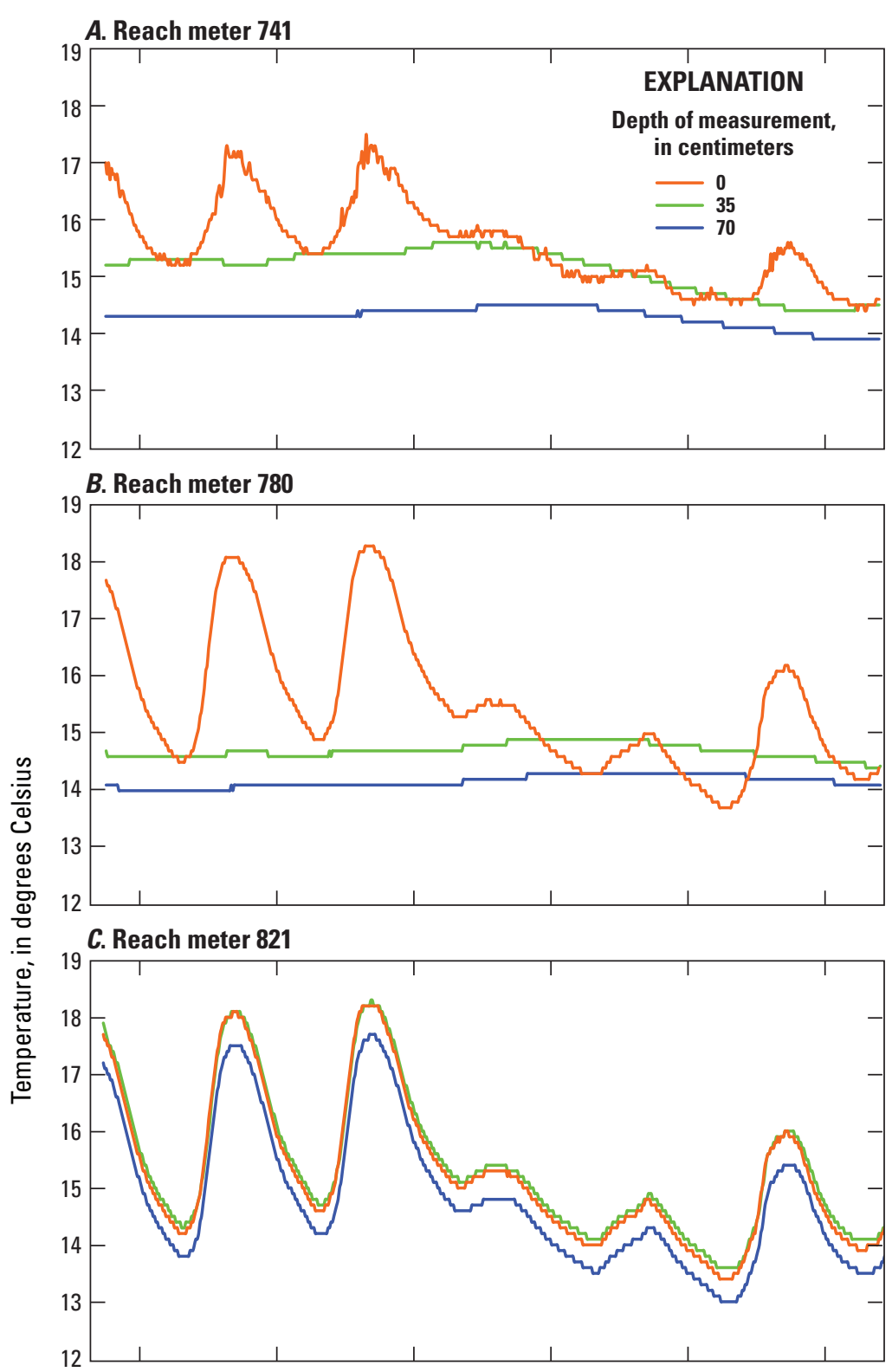

D. Reach meter 902

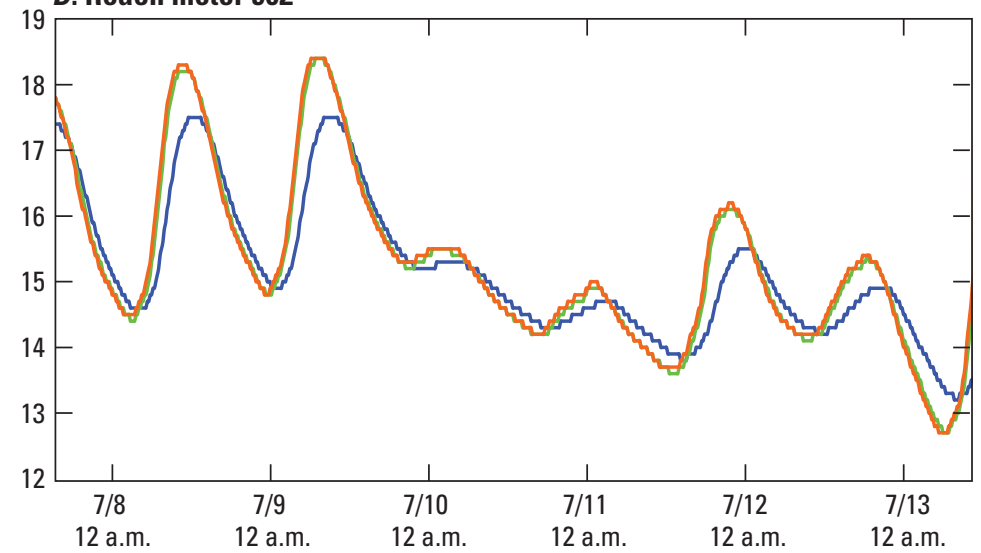




\section{Distribution of Information}

The longitudinal thermal profile data, survey data, and vertical temperature profile data are included in tables 1-3 and are available as Microsoft ${ }^{\circledR}$ Excel files for download at http:// dx.doi.org/10.3133/ds983.

Table 1. Near-streambed water temperature data for Iongitudinal thermal profile of Raging River, King County, western Washington, July 7-13, 2015.

Table 2. Location data for near-streambed water temperature measurement locations for longitudinal profile of Raging River, King County, western Washington.

Table 3. Water temperature data for vertical profiles at four locations along longitudinal temperature profile of Raging River, western Washington, July 7-13, 2015.

\section{Acknowledgments}

The authors would like to thank Josh Kubo and Andrew Miller of King County for assistance in collecting longitudinal temperature profiles, Bob Pendergast of King County for surveying the location of the fiber-optic cable, and Ray Timm (Cramer Fish Sciences) and Kate Macneale (King County) for cooperatively developing the fiber-optic distributed temperature sensor (FO-DTS) deployment with the authors. This study was jointly funded through a grant from the Snoqualmie Watershed Forum and the King County Flood Control District to King County Department of Natural Resources and Parks and the U.S. Geological Survey's Cooperative Water Program.

\section{References Cited}

Briggs, M.A., Lautz, L.K., McKenzie, J.M., Gordon, R.P., and Hare, D.K., 2012, Using high-resolution distributed temperature sensing to quantify spatial and temporal variability in vertical hyporheic flux: Water Resources Research, v. 48, p. W02527. [Also available at http://dx.doi. org/10.1029/2011WR011227.]
Gurnell, A.M., Piegay, H., Gregory, S.V., and Swanson, F.J., 2002, Large wood and fluvial processes: Freshwater Biology, v. 47, p. 601-619.

Hausner, M.B., Suárez, F., Glander, K.E., Giesen, N., Selker, J.S., and Tyler, S.W., 2011, Calibrating single-ended fiberoptic raman spectra distributed temperature sensing data: Sensors, v. 11, p. 10,859-10,879. [Also available at http:// dx.doi.org/10.3390/s111110859.]

Lowry, C.S., Walker, J.F., Hunt, R.J., and Anderson, M.P., 2007, Identifying spatial variability of groundwater discharge in a wetland stream using a distributed temperature sensor: Water Resources Research, v. 43, p. W10408. [Also available at http://dx.doi. org/10.1029/2007WR006145.]

Montgomery, D.R., and Piegay, H., 2003, Wood in riversInteractions with channel morphology and processes:

Geomorphology, v. 51, p. 1-5.

Pess, G.R., Liermann, M.C., McHenry, M.L., Peters, R.J., and Bennett, T.R., 2012, Juvenile salmon response to the placement of engineered log jams (ELJs) in the Elwha River, Washington State, USA: River Research and Applications, v. 28, p. 872-881. [Also available at http:// dx.doi.org/10.1002/rra.1481].

Sawyer, A.H., Cardenas, M.B., and Buttles, J., 2012, Hyporheic temperature dynamics and heat exchange near channel-spanning logs: Water Resources Research, v. 48, p. W01529. [Also available at http://dx.doi. org/10.1029/2011WR011200.]

Selker, J.S., Thévenaz, L., Huwald, H., Mallet, A., Luxemburg, W., van de Giesen, N., Stejskal, M., Zeman, J., Westhoff, M., and Parlange, M.B., 2006, Distributed fiberoptic temperature sensing for hydrologic systems: Water Resources Research, v. 42, no. 12, W12202. [Also available at http://dx.doi.org/10.1029/2006WR005326.]

Torgersen, C.E., Ebersole, J.L., and Keenan, D.M., 2012, Primer for identifying cold-water refuges to protect and restore thermal diversity in riverine landscapes: U.S. Environmental Protection Agency EPA 910-C-12-001, p. 91. 
Publishing support provided by the U.S. Geological Survey

Science Publishing Network, Tacoma Publishing Service Center

For more information concerning the research in this report, contact the Director, Washington Water Science Center

U.S. Geological Survey

934 Broadway, Suite 300

Tacoma, Washington 98402

http://wa.water.usgs.gov 


\section{कू
कू}

$\stackrel{8}{\infty}$

홍

$\stackrel{\mathscr{N}}{\text { 番 }}$

言

응

간

ฏ

폭

$\overrightarrow{\mathrm{T}}$

产

뭉

产

옿

गु

志

莡

$\sum_{0}$

䍜

$\sum_{2}$

产.

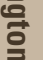

产

气

!

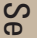

而

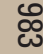

